\title{
Rediscovery of Assyriella rechingeri (Fuchs et Käufel, 1936) (Gastropoda Helicidae) in Karpathos Island (Dodecanese, Greece)
}

\author{
Mauro Grano' \& Cristina Cattaneo \\ ${ }^{1}$ Via Valcenischia 24, 00141 Rome, Italy; e-mail: elaphe58@yahoo.it \\ ${ }^{2}$ Via Eleonora d'Arborea 12,00162 Rome, Italy; e-mail: cristina.cattaneo76@libero.it
}

\begin{abstract}
The aim of this work is to confirm the occurrence of several living populations of Assyriella rechingeri (Fuchs et Käufel, 1936) (Gastropoda Helicidae) in Karpathos Island (Dodecanese, Greece) since the species was believed to be extinct in the past by some authors due to the discovery of only subfossils specimens. Its systematic status and the sympatry with Levantina spiriplana (Glaubrecht, 1993) and L. malziana (L. Pfeiffer, 1861) are discussed.
\end{abstract}

KEY WORDS Assyriella rechingeri; endemism; Kali Limni.

Received 26.02.2021; accepted 30.04.2021; published online 30.06.2021

\section{INTRODUCTION}

Assyriella rechingeri (Fuchs et Käufel, 1936) (Helicidae family, Helicinae subfamily, Helicini tribe) is part of a group of conchologically similar genera found between the central Mediterranean to Middle East and the Caucasus, which are close relative of the genus Helix Linnaeus, 1758. These genera are: Maltzanella P. Hesse, 1917; Lindholmiola P. Hesse, 1977; Levantina Kobelt, 1871; Assyriella Hesse, 1908; Gyrostomella Hesse, 1911, Isaurica Kobelt, 1901; Codringtonia Kobelt, 1898 (Hesse, 1920; Boettger \& Wenz, 1921; Subai, 1994).

Hesse (1908) had proposed the taxon Assyriella as a section of the Levantina for the species "guttata Olivier, 1804". Levantina had been split into the subgenera Codringtonia, Isaurica and Levantina s. str., and the latter was split into Assyriella, Levantina and Gyrostoma sections for shell anatomy reasons. Subsequently, Hesse (1918) elevated Assyriella to the rank of subgenus close to Levantina s. str. and Gyros- tomella (instead of Gyrostoma). As knowledge of species, localities, distribution areas and systematic position of the supraspecific taxa mentioned above increased, Assyriella was treated as a separate genus (Glaubrecht 1993a, 1993b; Subai, 1994). Molecular data are in Korabek et al. (2014).

Currently, Assyriella is considered paraphyletic with respect to Levantina (Korábek et al., 2014). The supraspecific taxa Codringtonia, Isaurica, Assyriella and Levantina evidently developed from a common root, just like the North African Gyrostomella. Schütt stated that Southeastern Anatolia was the radiation centre of the genus Assyriella (Schütt \& Subai, 1996). From here it may have spread in the Middle East and westward in some islands as Cyprus and Karpathos (Akbayin et al., 2001). The spreading of genus Assyriella towards west and south took place following the isolation and separation of Codringtonia, Isaurica and Levantina genera (Schütt \& Subai, 1996). Eustatic fluctuations in sea level, especially during the Messinian period 
(6 Ma), allowed the ancestors of Assyriella to cross the Mid Aegean Trench (MAT) in the Aegean and to colonize the Peloponnese, whose further development isolated the Codringtonia genus. Subsequently, sea level rise and tectonic uplift isolated the Isaurica genus. The very disjoint distribution of the Levantina genus on some Aegean islands and on the Syrian-Israeli mainland dates back to a subsequent lowering of the sea level during a Pleistocene glaciation (Pfannenstiel, 1944). The lowering of the coastline up to $200 \mathrm{~m}$ allowed migrations of freshwater and terrestrial molluscs along the Mediterranean coast favouring the spreading of the genus Assyriella. Furthermore, volcanic eruptions in the southern part of the Caucasus favoured the isolation of population with the emergence of geographically isolated species toward east (Schütt \& Subai, 1996).

The genus Assyriella Hesse, 1909 includes 13 species: A. bellardii (Mousson, 1854), A. ceratomma (Pfeiffer, 1856), A. cilicica (Kobelt, 1895), A. djulfensis (Dubois de Montpéreux, 1840), A. escheriana (Bourguignat, 1864), A. guttata, A. kurdistana (Pfeiffer, 1862), A. mardinensis (Kobelt, 1900), A. naegelei (Kobelt, 1901), A. ninivita (Galland, 1885), A. rechingeri (Fuchs \& Käufel, 1936), A. thospitis Schütt et Subai, 1996 and A. vanensis Schütt et Subai, 1996. Assyriella guttata (from the Gulf of Iskenderun to Mersin), A. bellardii (Cyprus) and $A$. rechingeri are the westernmost representatives of the genus.

Assyriella rechingeri is an exclusive endemic species of Karpathos Island in the Dodecanese Archipelago (Greece) and perhaps is a relic population of the Assyriella group. The relic occurrence of $A$. rechingeri on Karpathos and $A$. bellardii on Cyprus suggests that Assyriella was once more widely distributed in the eastern Mediterranean as it is even today (Schütt \& Subai, 1996) and can also be interpreted as allospecies of a widely distributed A. guttata superspecies (Glaubrecht, 1994). It could be argued that the Assyriella populations were separated from the Assyriella distributional area (Eastern Anatolia) after Miocene due to climatic and geological changes. Palaeogeographical data reveal that Karpathos was detached from the island chain of Rhodes and thus from the mainland of Asia Minor as early as in the late Miocene (5-6 Ma). Thus, the ancestors of rechin- geri must have reached the island by this time. Karpathos was reintegrated with the mainland during the Messinian salinity crisis (5-6 Ma) and was joined with Rhodes and Anatolia in Lower Pliocene (Daams \& Van der Weerd, 1980), but presumably remained isolated at the end of the middle Pliocene and during the whole Pleistocene (Dermitzakis, 1991). This isolation would have led the Assyriella population of Karpathos and Cyprus to an evolutionary change and to an adaptation to different environmental conditions. Hence, A. rechingeri on Karpathos and bellardii on Cyprus can be construed as vicarious taxa of the Assyriella species group. A similar disjoint distribution in the eastern Mediterranean can be observed in Levantina spiriplana (Glaubrecht, 1993). The Eastern Mediterranean land snails Levantina displays a disjunct range spanning the Middle East (Levant), Cyprus, few locations along the Aegean Turkish coast between Bodrum and Datça, the islands of Rhodes and Karpathos and a few surrounding islets (Dodecanese). In the Levant, it is represented by two species parapatrically distributed: $L$. caesareana (Mousson, 1854) in the north and L. hierosolyma (Mousson, 1854) in the south. In the Dodecanese L. spiriplana and L. malziana (L. Pfeiffer, 1861) occur together (Ketmaier \& Glaubrecht, 2015). In Karpathos, both species are parapatrically distributed, and leave in sympatry with $A$. rechingeri sharing area up to $500 \mathrm{~m}$ a.s.l.

\section{MATERIALS AND METHODS}

\section{Study area}

Karpathos is the second largest Dodecanese island after Rhodes and lies in the SE Aegean Sea, halfway between Crete and Rhodes $(39 \mathrm{~km}$ from Crete and $25 \mathrm{~km}$ from Rhodes). The island is 49 $\mathrm{km}$ long and $15 \mathrm{~km}$ wide and covers an area of 302.15 square kilometres. Together with Kasos and Armathia in the southwest, the nearby Saria in the north and several offshore islets, Karpathos forms the Karpathos Archipelago and is a constituent part of the South Aegean Island Arc (Greuter et al., 1983). The three larger islands contain widespread mountainous areas with some higher peaks, culminating on Karpathos in the Kali 
Limni (1215 m), on Kasos in the Megalo Prionas $(601 \mathrm{~m})$, and on Saria in the Pachy Vouno $(629 \mathrm{~m})$ (Grano \& Cattaneo, 2019). On Karpathos the only flat areas are near Afiartis in the south, near Lastos in the centre, and Avlona in the north. Karpathos is built up of limestone and dolomitic limestone (Jurassic-Eocene) in the northernmost part, flysch (Eocene) in most of the northern and the southern part, Neogene deposit in the southernmost area. The central part of the island corresponding to the Kali Limni Mountain complex, the area near Menetes (south) and Pigadia (south-east), are constituted by the Kalilimni Unit, a parautochthonous carbonate platform (Jurassic-Eocene) overlaid by the Xindothio Unit (Triassic-Cretaceous) almost built up of ophiolites (Cordey \& Quillévéré, 2019).

\section{Methods}

Our naturalistic research has been carried out on Karpathos twice, the first from 28 July to 17 August 2019 and the second from 10 August to 17 August 2020. During the second session (2020) A. rechingeri was found in four different areas. For an optimal research, the entire island has been only visited on foot along roads, paths, and streams. Only empty shells were found in several sites - which are mentioned below - therefore only a conchological study of the specimens was possible to perform. The shells were cleaned with water and a brush after being soaked for about two minutes in a solution with $60 \%$ water $(\mathrm{H} 2 \mathrm{O})$ and $40 \% \mathrm{NaClO}$. The specimens are kept in the private collection of one of the authors (MG, Rome, Italy). For the taxonomy of this species the Fauna Europaea Project (Bank, 2017) and MolluscaBase (2021) has been followed.

The collected material is of 12 specimens of which 5 examined (Table 1). The shell variables shown in Fig. 1 were measured on the specimens in millimeters with a calliper of $1 / 100 \mathrm{~mm}$ precision. A-B: Shell Height (ShH); A-C: Spire Height (SpH); D-G: Shell Diameter (ShD); E-F: Truncation Width (TrW); E-G: Aperture Width (ApW); $\mathrm{H}-\mathrm{I}$ : Aperture Height (ApH).

The specimens of the Figs. 2-4 are from Profitis Ilias $\left(35^{\circ} 37^{\prime} 20^{\prime \prime} \mathrm{N}-27^{\circ} 08^{\prime} 09^{\prime \prime} \mathrm{E} 500 \mathrm{~m}\right)$, the specimen of the Fig. 5 is from Profitis Ilias $\left(35^{\circ} 37^{\prime} 20^{\prime \prime} \mathrm{N}-27^{\circ} 08^{\prime} 09^{\prime \prime} \mathrm{E} 500 \mathrm{~m}\right)$ (Fig. 2), and the specimen of the Fig. 6 is from Kali Limni $\left(35^{\circ} 35^{\prime} 42^{\prime \prime} \mathrm{N}-27^{\circ} 07^{\prime} 25^{\prime \prime} \mathrm{E} 1100 \mathrm{~m}\right)$.

\section{RESULTS}

Assyriella rechingeri (Fuchs et Käufel, 1936)

1936. Levantina (Codringtonia) rechingeri Fuchs \& Käufel, Arch. Naturgesch., (NF) 5 (4): 658, Abb. XI, F. 35 A-C, locus typicus: Insel Karpathos: Gipfelstock des Kalolimni, 8001000 m. Holotypus: NMW 535 (lost).

1939. Codringtonia (Isaurica) rechingeri, - K. L. Pfeiffer \& Wächtler, Arch. Molluskenkunde, 71 (2/3): 57, Abb. 10c (as Isaurica rechingeri).

1987. Codringtonia intusplicata rechingeri, - Zilch, Arch. Molluskenkunde, 117 (1986) (4/6): 245.

1994. Assyriella rechingeri, - Glaubrecht, Verh. naturwiss. Ver. Hamburg, (NF) 34: 373, F. 1 (Karte), F. 2 (shell).

Shell dirty white with yellowish hue, with five brown colour bands, often interrupted by white zigzag lines, but blurrier than in L. spiriplana. Smooth, white aperture with a short and distinct callus at the columellar base, peristome well reflected, sharp, with margins connected by a thin parietal layer, umbilicus narrow and deep, partly covered by the reflected columellar margin. The size is $15.5-21 \times 31-38 \mathrm{~mm}$. Named in honour of the Austrian botanist and phytogeografer Karl Heinz Rechingher (Wien 16 October 1906 - Wien 30 December 1998).

Based on a single heavily corroded specimen collected in 1935 by Rechinger on the Kali Limni massif, the species was initially described as Levantina (Codringtonia) rechingeri Fuchs et Käufel, 1936, type locality "Karpathos, Kalolimni mountain peak region, 800-1000 m" (Fuchs \& Käufel, 1936). The holotype is deposited in the Naturhistorisches Museum of Wien MNW 535 (lost, Schütt $\&$ Subai 1996). Subsequently, Pfeiffer found other specimens (Pfeiffer \& Wächtler, 1939) and based on the shell morphology and on biogeographical reasons, suggested to assign the taxon to Isaurica Kobelt, 1901 rather than to the Greek Codringtonia Kobelt, 1898. Later, Glaubrecht (1994) assigned rechingeri from Karpathos to the Assyriella genus, as already supposed by Subai (1994), highlighting the differences with Isaurica. The latter differs from rechingeri by several features such as the larger and spherical shell, the diameter-to-callus length ratio, and the umbilical region always com- 
pletely covered. Instead, rechingeri shows a reinforced, everted aperture lip and the umbilicus almost entirely open. Furthermore, all rechingeri shells show a tooth-like protuberance on the lower lip that is less pronounced in the Isaurica forms (Glaubrecht, 1994). This tooth like projection and broadly everted aperture lip, as in rechingeri, are features only for the genus Assyriella, especially for its type species A. guttata and for A. bellardii. In addition, both the latter two species have a conspicuous, at most half-covered, umbilicus. It is worth noting that Assyriella like Levantina and the northern African Gyrostomella includes snails displaying either a wide-open umbilicus or an almost covered umbilical region. In Assyriella as in Levantina the discrepancy between umbilicate and non-umbilicate forms is still regarded relevant enough to justify different species assignments (Glaubrecht, 1994; Ketmaier \& Glaubrecht, 2015).

Assyriella rechingeri is considered CR, Critically Endangered, in the EU Red List. The AnimalBase database www.animalbase.uni-goettingen.de report: "Rare, usually only subfossil shells are found. It is not known if live animals are still present somewhere, and if yes, by which factors they are threatened. Glaubrecht 1994 suspected that the species was extinct".

\section{DISCUSSION}

The specimens from Kali Limni are significantly smaller than those of Profitis Ilias (Figs. 26 ). The specimens have been found at different

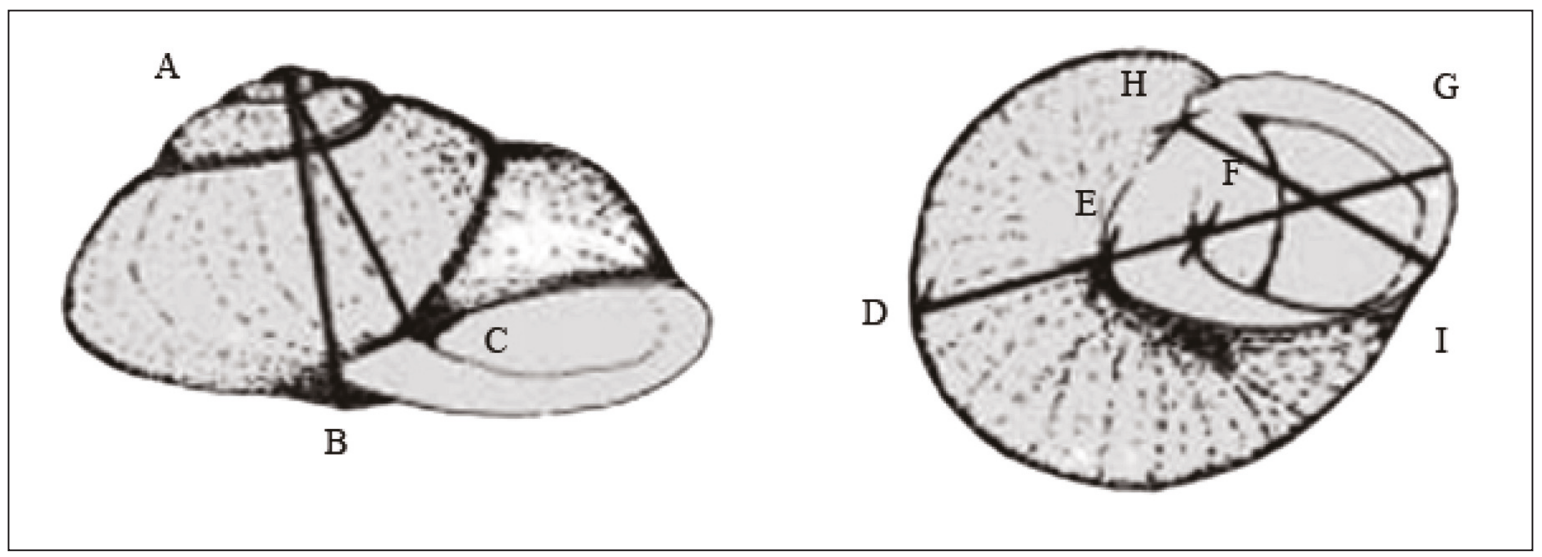

Figure 1. Measurements of shell variables (modified by Akbayin et al., 2001).

\begin{tabular}{|c|c|c|c|c|c|}
\hline Shell variable $(\mathrm{mm})$ & A & B & C & D & E \\
\hline Shell diameter $(\mathrm{ShD})$ & 30.5 & 28.0 & 31.0 & 36.0 & 37.5 \\
\hline Shell Height $(\mathrm{ShH})$ & 13.0 & 13.0 & 14.5 & 17.0 & 18.0 \\
\hline Aperture Height $(\mathrm{ApH})$ & 16.0 & 14.0 & 15.5 & 19.0 & 19.5 \\
\hline Aperture Width $(\mathrm{ApW})$ & 16.5 & 17.0 & 18.0 & 21.0 & 21.5 \\
\hline Spire Height $(\mathrm{SpH})$ & 12.0 & 13.0 & 13.5 & 16.0 & 16.5 \\
\hline Truncation Width $(\mathrm{TrW})$ & 2.0 & 2.5 & 2.5 & 3.0 & 4.0 \\
\hline
\end{tabular}




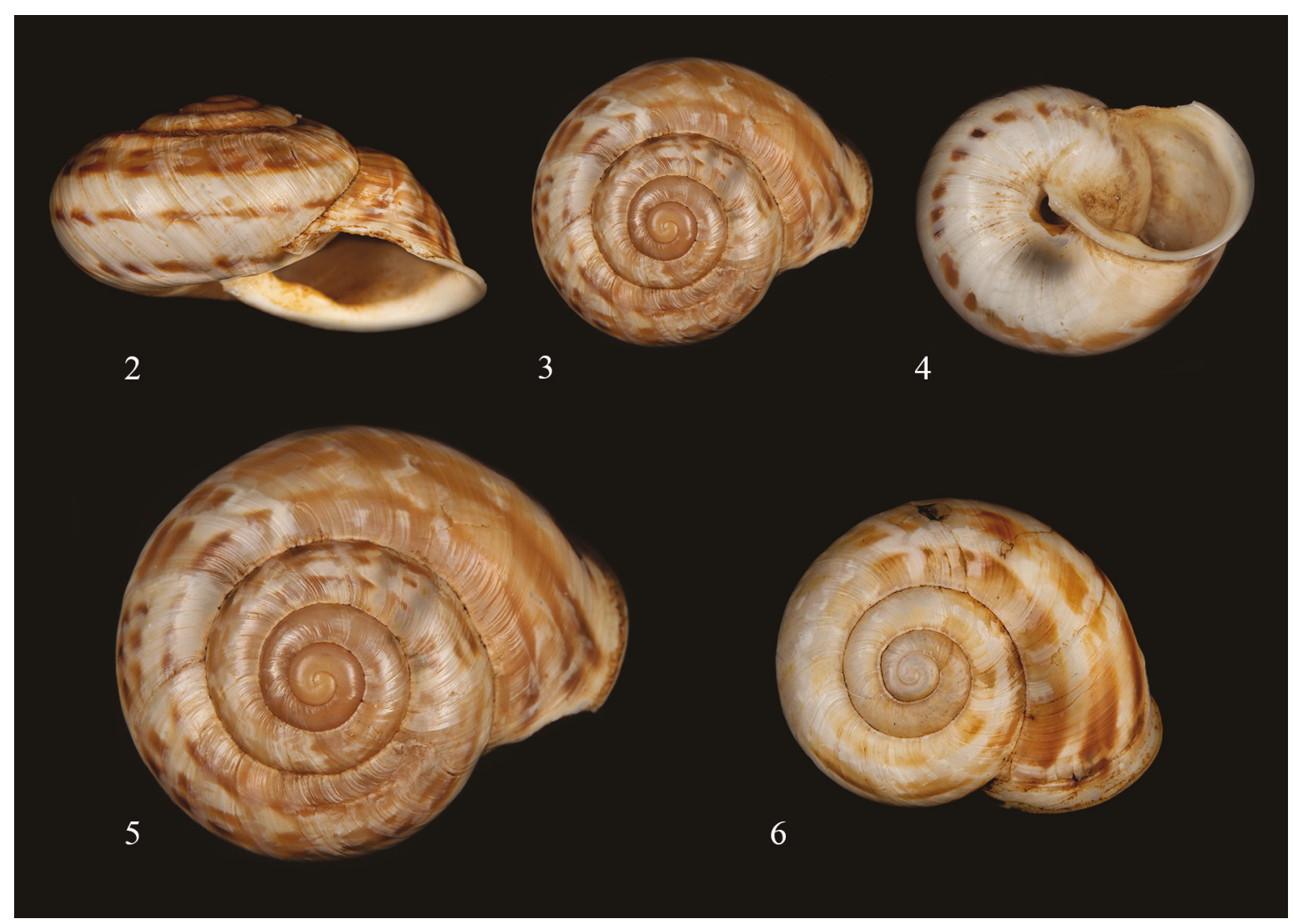

Figures 2-6. Assyriella rechingeri from Karpatos island. Figs. 2-4: Profitis Ilias.

Fig. 5: Profitis Ilias. Fig. 6: Kali Limni.

altitudes (from 500 to $1100 \mathrm{~m}$ a.s.1.) in several sites all included in the Kali Limni massif: Mt. Kali Limni, Mt. Kollas and Mt. Profitis Ilias, Also the specimens collected by Pfeiffer (1937) and by Glaubrecht (1989), come all from Mt. Kali Limni and from the mountainous reliefs in the nearby as Mt. Melloura (south-east of Lastos), Mt. Kollas and Mt. Volada (Glaubrecht, 1994). We confirm as stated by Glaubrecht (1994), that it seems to be no evidence of the presence of the species in other parts of the island. Assyriella rechingeri lives in sympatry in Karpathos with L. spiriplana (Olivier, 1801) and L. malziana, which show a parapatric distribution. Both the latter species are abundantly present throughout the island with the exception for the Kali Limni from 500 to maximum height. Our discovery of some specimens of $A$. rechingeri together with L. spiriplana on Mt. Kollas at an altitude of $500 \mathrm{~m}$ would suggest an overlap between the distribution range of both species. However, from $500 \mathrm{~m}$ up to the summit of Mt. Kali Limni, the area is occupied only by $A$. rechingeri. Previous competition with Levantina genus may have caused the limited distribution of $A$. rechingeri in the Kali Limni massif (Glaubrecht, 1994). Competition between these related species, with a probably similar ecological niche, would have involved a specialization of $A$. rechingeri to occupy a niche characterized by specific climatic (higher altitude) and edaphic conditions. It is noteworthy that on Cyprus we have the same situation, as both the aforementioned species of Levantina occur in sympatry with $A$. bellardii Mousson, 1854 (Glaubrecht, 1994).

\section{CONCLUSIONS}

The summer period during which our research took place did not allow us to find live specimens of $A$. rechingeri. However, numerous specimens were found in excellent condition and therefore recently died. In addition, some specimens were also 


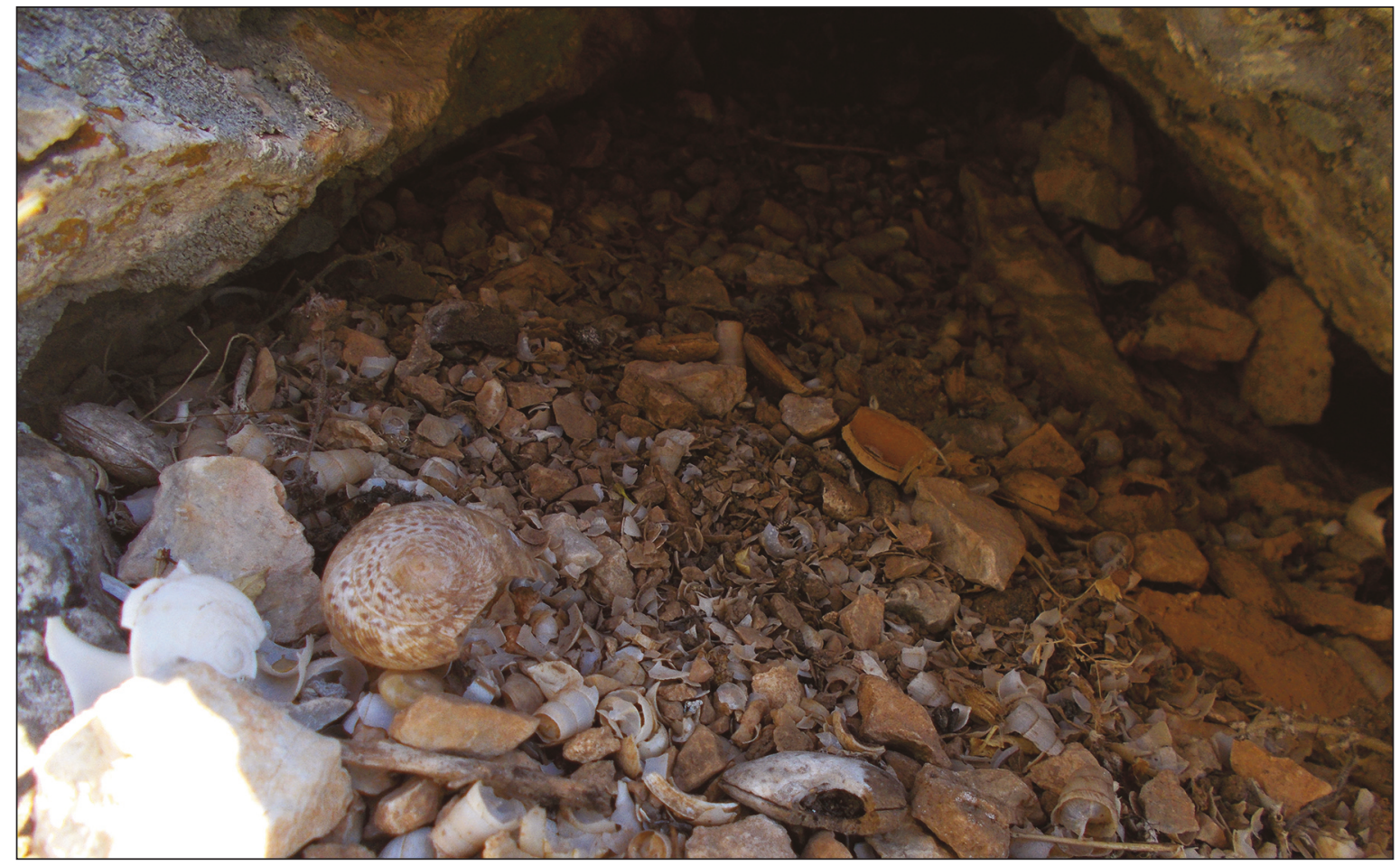

Figure 7. Entrance of the burrow of Rattus rattus predator of molluses (Karpatos island).

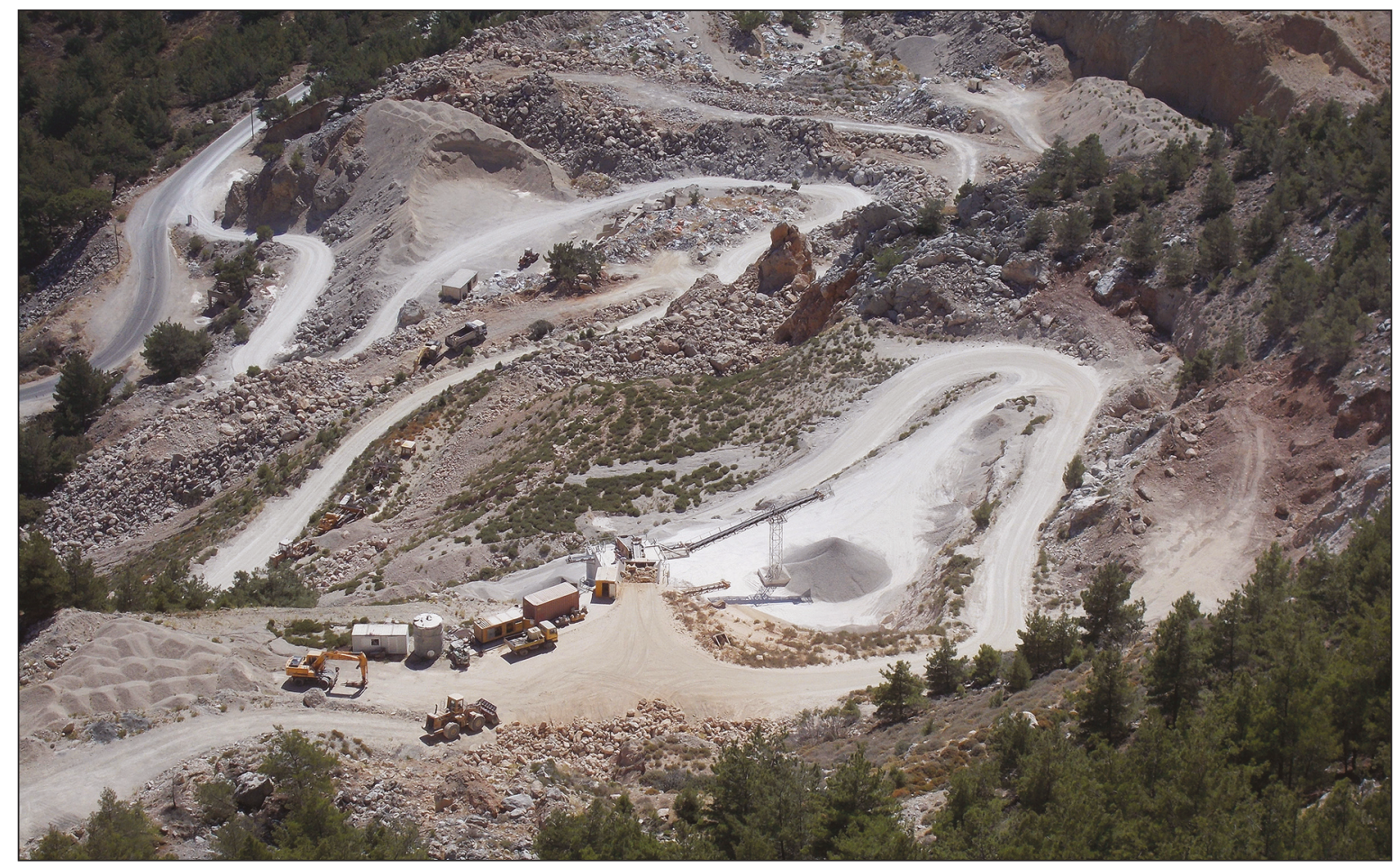

Figure 8. Limestone quarries and roads on the eastern slope of the Mt. Kollas (Karpatos island). 
encountered at the entrance of the numerous burrows of Rattus rattus (Linnaeus, 1758) predators of molluscs in arid environments (Fig. 7). Glaubrecht (1994) hypothesized that A. rechingeri may be extinct, fortunately, we can claim that this species is not extinct even if its presence is rare with a very localized distribution. It could be a relic species and deserves to be overlooked like many other species of land snails, animals and rare and endemic plants that occur in Karpathos and in particular on the Kali Limni massif. In the last year (pers. obs.) limestone quarries and roads have been built on the eastern flank of the Mt. Kollas (Fig. 8). The tourism sector is increasingly developing in Karpathos and this involves the extraction of large quantities of limestone for the construction of new buildings and hotels. This represents a serious damage for the environment since peculiar habitats for the fauna and for endemic plants have already been eradicated.

\section{ACKNOWLEDGEMENTS}

We are grateful to Fabio Liberto (Cefalù, Italy) and Joop Eikenboom (Melissant, The Netherlands) for their valuable help and advice. Also, a special thanks to Roberto Nistri for the "still life" photos.

\section{REFERENCES}

Akbayin H., Hevedanli M. \& Şeşen R., 2001. Some Assyriella species in South East Anatolia in Turkey differentiated by multivariate statistical analysis (Gastropoda: Pulmonata, Helicidae). Turkey Journal of Zoology, 25: 1-9.

Bank R.A., 2017. Fauna Europaea Project. Checklist of the land and freshwater Gastropoda of Europe, $176 \mathrm{pp}$.

Boettger C.R. \& Wenz W., 1921. Zur Systematik der zu den Heliciden subfamilien Campylaeinae und Helicinae gehörigen tertiären Landschnecken. Archiv für Molluskenkunde, 53: 6-55.

Cordey F. \& Quillévéré F., 2019. Reassessing the age of Karpathos ophiolite (Dodecanese, Greece): consequences for Aegean correlations and Neotethys evolution. Geological Magazine, 157: 1-12. https://doi.org/10.1017/S0016756819000657

Daams R. \& Weerd A. Van de, 1980. Early Pliocene small mammals from the Aegean Island of Karpathos (Greece) and their palaeogeographic significance. Geologie en Mijnbouw, 59: 327-331.
Dermitzakis M.D., 1991. Paleogeography, geodynamic process and event stratigraphy during the Late Cenozoic of the Aegean area. In: Azzaroli A. (Ed.), Biogeographical aspects of insularity. Atti dei Convegni Lincei, 85: 263-288. Rome (Accademia Nazionale dei Lincei).

Glaubrecht M., 1993a. Die Landschnecke Levantine spiriplana im Ostmediterran: Johanniter-KreuzritterThese oder Paleogeographie? Natur und Museum, Frankfurt a.M., 123: 97-114.

Glaubrecht M., 1993b. Entdeckungsgeschichte von Landschnecken der Gattung Levantina (Pulmonata, Helicinae). Mitteilungen der Deutschen Malakozoologischen Gesellschaft, 50/51: 33-40.

Glaubrecht M., 1994. Systematic and biogeography of Assyriella rechingeri (Gastropoda, Pulmonata, Helicidae) on Karpathos, Greece. Verh. Naturwiss. Ver. Hamburg, 34: 373-384.

Grano M. \& Cattaneo C., 2019. First record of Roughtailed Agama Stellagama stellio (Linnaeus, 1758) (Reptilia, Agamidae) from Karpathos island (Dodecanese, Greece). Parnassiana Archives, 7: 51-54.

Greuter W., Pleger R. \& Raus T., 1983. The vascular flora of the Karpathos island group (Dodecanesos, Greece). A preliminary checklist. Willdenowia, 13: 43-78.

Hesse P., 1908. Die systematische Stellung von Helix leachii Fér. und gyrostoma Fér. Zoologische Jahrbücher, 27: 313-320.

Hesse P., 1918. Das Genus Levantina Kob. Nachrichtenblatt der Bayerischen Bayerischen Malakozoologischen Gesellschaft, 50: 40-47.

Hesse P., 1920. Iconographie der Land \& SüsswasserMollusken mit vorzüglicher Berücksichtigung der europäischen noch nicht abgebildeten Arten von E.A. Rossmässler. N.F. 23, 1-262, pl. 631-660. Wiesbaden: Kreidel.

Ketmaier V. \& Glaubrecht M., 2015. The legacy of the Crusaders: Complex history of colonization and anthropochory in the land snails Levantina (Gastropoda, Pulmonata) in the Eastern Mediterranean. Zoosystematics and Evolution, 91: 81-89. https://doi.org/10.3897/zse.91.4693

Korábek O., Jurickova L. \& Petrusek A., 2014. Resurrecting Helix straminea, a forgotten escargot with trans-Adriatic distribution: first insights into the genetic variation within the genus Helix (Gastropoda: Pulmonata). Zoological Journal of the Linnaean Society, 171: 72-91. https://doi.org/10.1111/zoj.12122

MolluscaBase, 2021. MolluscaBase. Accessed at http://www.molluscabase.org on 2021-01-05. https://doi.org/10.14284/448

Pfannenstiel M., 1944. Die diluvialen entvicklungsstadien und die Urgeschiccthe von Dardanellen. Mar- 
marameer und Bosphorus. Diluvial, Geologie und Klima, Geologische Rundschau, 3-4 (7-8), 324-434.

Pfeiffer K.L. \& Wächtler W., 1939. Über Codringtonia und Isaurica. Archiv für Molluskenkunde, 71: 57-74.

Schütt H. \& Subai P., 1996. Revision der Gattung Assyriella P. Hesse 1908 (Gastropoda: Pulmonata: He- licidae: Helicinae). Archiv für Molluskenkunde, 117161.

Subai P., 1994. Vergleich der mit Levantina verwandten großen Heliciden sowie Revision der Gattung lsaurica (Kobelt) (Gastropoda: Helicidae). Archiv für Molluskenkunde, 123: 49-87. 